\title{
Analysis Of Factors Affecting Customer Commitment And Customer Loyalty Customer Service ERP Systems PT. Global Industri Technology Solusi (PT. Gits) In Surabaya
}

\author{
Redemptus Edward Wibisono, Oliandes ${ }^{\mathrm{b}}$, Amelia $^{\mathrm{c} *}$ \\ a edwardwibisono25@gmail.com \\ ${ }^{a}$ Master of Management Student at Pelita Harapan University, Surabaya 60234, Indonesia \\ ${ }^{b, c}$ The Lecturer of Master of Management at Pelita Harapan University, Surabaya 60234, Indonesia
}

\begin{abstract}
The development of Enterprise Resource Planning or ERP technology provides opportunities for ERP service companies in Indonesia especially in the city of Surabaya. This development is also driven by the needs of manufacturing or service industry players who want to integrate all their departments, in order to produce a strong analysis so that company leaders can easily make decisions. One of the service companies that offer ERP implementation services is PT. Global Industri Teknologi Solusi (PT. GITS). The first time PT. Global Industri Teknologi Solusi was founded in 2012 in Surabaya City. This study aims to determine how the influence of Ethical Sales, Sales Expertise, Service Performance, Corporate Reputation, Corporate Performance, Relationship Quality of Salesperson and Relationship Quality Of Institution on Customer Commitment in forming Customer Loyalty to customers of PT. GITS in Surabaya. The benefit expected from this research is to contribute to the development of theory and marketing research which is beneficial for PT. Global Industri Teknologi Solusi in examining the influence of the variables Ethical Sales, Sales Expertise, Service Performance, Corporate Reputation, Corporate Performance, Relationship Quality Of Salesperson and Relationship Quality Of Institution on Customer Commitment in forming Customer Loyalty. This research is a research with quantitative methods with data processing using SPSS 22.0. Data collection was carried out by distributing questionnaires to 31 respondents who had become customers of PT. GITS, and domiciled in Surabaya. The results showed that the variable that had the greatest influence was Customer Commitment to the Customer Loyalty variable of 0.680 ; then the second largest variable is the Relationship Quality of Salesperson to the Customer Commitment variable of 0.656; the third largest was the Corporate Reputation variable on the Quality Of Institution Relationship, amounting to 0.542 ; the fourth largest variable Service Performance on the Quality Of Salesperson Relationship of 0.411 ; the fifth largest variable of Relationship Quality Of Institution to Customer Commitment amounted to 0.327; the sixth largest Sales Expertise on the Quality Of Salesperson Relationship of 0.320; the seventh largest Ethical Salesperson to the Quality Of Salesperson Relationship of 0.283; the eighth largest is the Relationship Quality Of Salesperson to the Quality Of Institution Relationship of 0.257; the ninth largest was Corporate Performance on Relationship Quality Of Institution, amounting to 0.211.
\end{abstract}

Keywords: Corporate Reputation; Relationship Quality; Ethics; Loyalty.

\section{Introduction}

Currently, information system technology in the world has been growing from year to year. The development of increasingly advanced technology can affect various aspects of human life, especially in the business world. The use of information system technology in all lines of business is considered capable of increasing efficiency and effectiveness in a company's business processes. Companies that have successfully implemented information system technology can easily control, process, and analyze data more accurately so that all decisions are made based on original data. Due to the growing development of technology, many 
companies are competing to use it to improve the performance of their companies. One of the information system technologies that companies can apply or use in improving their business performance is the Enterprise Resource Planning System or abbreviated as ERP System.

Seeing that ERP systems that exist throughout the world today have also experienced developments since the 1970s. Not a few companies also use this ERP technology to become their business solutions, both small to large companies. The Global ERP Software market which is valued at approximately USD 33.7 billion in 2017 is expected to grow at a healthy growth rate of more than 7.4\% over the forecast period 20182025. Such growth rates indicate that ERP systems are increasingly being used by many companies and will continue to grow worldwide over the next few years. Conventionally throughout the world this ERP System is widely used for back office operations, which include production, accounting, inventory control, order management and others (http://www.nxtgenreports.com, downloaded on May 25, 2020).

Every year the ERP system develops in order to support the business processes of each company that implements it. ERP itself originated from the development of the MRP II (Manufacturing Resources Planning II) system which was popular in the 1980s. Then in the 1990s one of the well-known companies in Indonesia successfully implemented an ERP system using SAP. This company is PT Astra International. SAP itself is one of the ERP System vendors which is quite well known not only among domestic businessmen but also throughout the world. In the 90s, ERP in Indonesia began to develop rapidly with the appearance of better platforms and hardware than ever before (https://aplikasibisnis.net, downloaded on May 26, 2020).

In East Java, especially in the city of Surabaya, there is a vendor that provides ERP system services. The name of this company is PT. Global Industri Teknologi Solusi or abbreviated as GITS. This company was founded in 2012 by several professional consultants who are competent and experienced every year with the same and strong vision to help their customers generate more value for their business to create a better future. GITS (short name) is a Gold Microsoft Certified Partner who specializes in the implementation, support and development of Enterprise Resource Planning (ERP) services to help its customers create a competitive advantage and deliver effective businesses. (GITS company profile, 2020)

In the city of Surabaya there are also several ERP System vendors that can offer their services to prospective customers. Wahana Cipta Sinatria is an experienced company in IT (Information Technology) and is also known as ERP Company, which is located at Graha SA Building, Jalan Raya Gubeng, Surabaya. As reported on Wahana Cipta Sinatria's website, this company has been around for a long time since 1995 which is also a partner of Microsoft by bringing its flagship ERP product, Microsoft Dynamics 365 . (https://www.wahanaciptasinatria.co.id, downloaded on July 20, 2020)

There are also other GITS competitors, namely Kano, a company that is both engaged in IT, specifically software engineering, ERP implementation, and company big data analysis. The canoe is centered on Jl. Sambas No 1, Wonokromo District, Surabaya has more than 10 years of experience in ERP implementation. There are many products offered by Kano to potential customers in order to provide maximum service and according to their wishes. For example, there are Microsoft Dynamics 365, Odoo, AWS, and many other applications. (https://www.kanosolution.com, downloaded on July 20, 2020)

The competition that occurs between ERP service companies makes them motivated to carry out development in order to create customer loyalty from the services provided. Almost all types of companies, be they manufacturing or service companies, compete in order to create customer loyalty in their business. Customer loyalty according to Siagian and Cahyono (2014), states that a firmly held commitment to repurchasing selected products or services consistently in the future, leading to repeated purchases of products or services with the same brand, even though there are situational influences and marketing efforts. the potential to cause the behavior to switch to a different brand of products or services. One company which is proof that PT. GITS can create customer loyalty to the service products offered, namely PT. Dharma for Authority. Previously, DGW (the name of PT. Dharma Guna Wibawa) in 2017 which still used the old 
version of the ERP system, namely Business Central, but was still based on Microsoft's local data (onprem). DGW is upgrading its product, which initially used local data, now it uses the cloud database offered by GITS so that they can maximize the system they have built earlier. Not only that, DGW also trusts GITS to create and implement several customization modules for DGW demands. The DGW implementation project has also gone live and was successful. The system development is still being carried out to create a more integrated process. BC on cloud implementation at PT. DGW has produced an integrated system that facilitates operational management of PT. DGW thereby increasing cost and time effectiveness. (GITS company profile, 2020)

Talking about commitment, GITS has carried out several ERP system implementations into a company's business. System implementation also requires a strong commitment from both parties, both from the GITS side and from the customer / client side. Why does GITS need to build a commitment to its customers? This was built by PT. GITS in order to achieve these customer goals using ERP system services from PT. GITS is to integrate their business more efficiently. Commitments are formed before any training period or live implementation into the customer's company system. As stated by Pitchard et al., Thorsten et al. (2002) revealed that customer commitment has a strong correlation with customer loyalty.

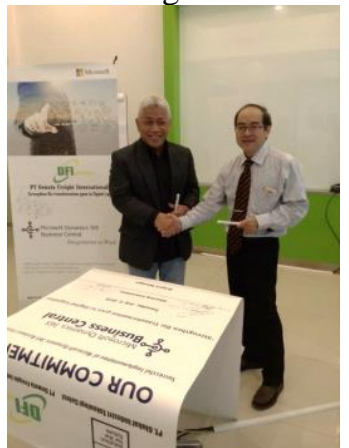

Figure 1.1 Signs of Commitment Handling of Implementation Projects by PT. Dewata Freight International Source: Company Profile GITS 2020

Relationship quality is one of the mediations that can create a customer commitment and then also affects customer loyalty. In previous studies, there were 2 relationship quality that could affect customer commitment, including relationship quality of salespeople, and second, relationship quality of institutions. According to Lupiyodi (2012), relationship quality of salesperson is an activity or activity carried out by a company in order to increase the usefulness of a product or service offered by a company in order to create customer satisfaction and create a harmonious relationship between the two. GITS has a variety of services that can be offered to customers.

The next most important relationship quality is the relationship quality of institutions. Whereas the relationship quality of institution, according to Angelova (2011), states that as a measure whether an organization has the ability to not only meet customer needs but also exceed customer expectations through products or services. There are so many services that GITS offers to customers in order to achieve customer goals and desires. These services include; (1) IT Consultation; (2) New Implementation; (3) System Upgrade Implementation; (4) Continues Improvement; (5) Training and Education; (6) Dedicate Customer Support. All these types of services are offered by GITS sales to their customers so they can choose which service is right for them and needed by them. GITS will also provide good input and suggestions before starting the project.

The importance of a company that is supported by a salesperson or salesperson who is reliable, competent and has ethical sales behavior in marketing the products sold by the company. According to 
Crosby et al., (1990), ethical sales is a relevant competency related to products, and is most often displayed in the form of information provided by salespeople. For a service company, ethical sales is an important thing that must be in the organization of a company in order to maintain a relationship with customers. The ethics of a salesperson in building relationships with his customers, among others; (1) No bribery; (2) Information overload of the product; (3) Price discrimination; (4) Forcing to buy each other (https://www.proweb.co.id, downloaded on 29 May 2020).

As is in one of the company values of PT. GITS that "supply the newest updated technology that brings businesses to gain more competitive advantage", which means that the company will provide good offers for potential customers and existing customers to be able to develop their business. All the latest information provided by GITS salesperson to customers according to their needs in the company. This reflects ethical sales who provide product or service information that is needed by customers of PT. GITS.

It is important that the sales team's ability is built in order to have extensive knowledge about the business world, especially the sales team from PT. GITS. Companies like GITS which are engaged in ERP system services require that their sales teams have extensive knowledge in the business world, ranging from industry, services, retail, and others. Not only that, salespeople must also have good product knowledge which will later become the spearhead in marketing the service products offered to customers. This refers to sales expertise or the ability of salespeople to market their products. According to Lagace et al., (1991) sales expertise is defined as knowledge, experience, or skills that are relevant to certain topics that individuals in an organization or company have. The sales team from GITS is equipped with extensive knowledge about the products that will be offered to their customers according to their needs and demands. One example of a customer of PT. Various Indonesian Tuna who already know ERP before getting to know GITS. They asked GITS and believed that GITS could integrate existing systems into one so that the system would run efficiently. Therefore the sales team offers Microsoft Business Central which can adopt their old modules into the new system, and is able to streamline the business processes of PT. ATI itself.

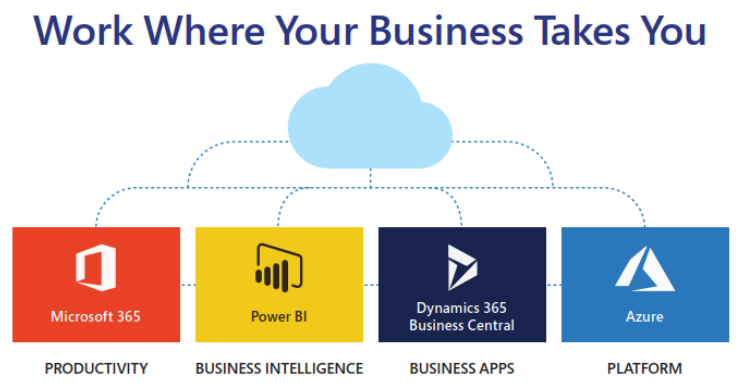

Figure 1.2 Types of Products of PT. GITS

Source: Company Profile GITS 2020

In the component of a salesperson / salesperson, there is a value that is also important in building longterm relationships or relationships with customers, namely service performance. According to Vroom (2012) service performance is a result of work in quality and quantity achieved by an employee in carrying out his duties in accordance with the responsibilities assigned to him, especially in service companies, these employees must be able to become friends who understand the needs of their customers. . Since 2012 GITS has been able to provide good service in order to maintain relationships with its customers. Especially for customers who are still in the stage of implementing systems within the company, one of the services of GITS is Training and Education. Training and Education is offered to GITS customers with a competent consultant to prepare end-users for the implementation of a new ERP system into the company. Therefore, this has made an important value for GITS "give the best and trustable consultants to help our customers achieve their goals" 


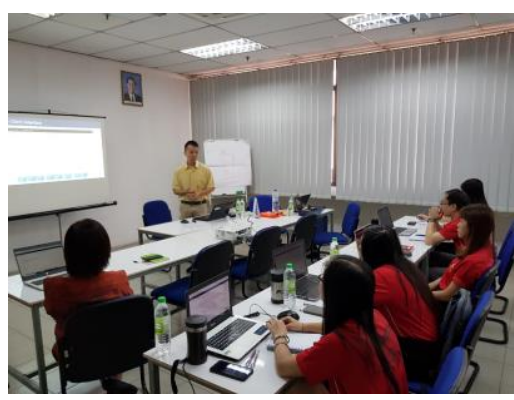

Figure 1.3 One of the GITS Consultants Providing Training and Education to Clients in Penang - Malaysia Source: Company Profile GITS 2020

Service companies such as GITS, which are engaged in technology, especially ERP systems, also emphasize their company's reputation in order to establish good relationships with their customers (relationship quality). According to Caruana, (1997) corporate reputation is the perception of customers and self-confidence in the organization as a result of past organizational interactions both short and long term, which includes product impressions, anticipation of consistency in product and service quality, with no negative perspective. "Treat our customers personally in order to get their confidence with our services including analysis, design, training, and implementation", is an important value for the reputation of GITS that has been built since 2012 with the aim of being able to provide the best service, and to provide more trust. to its customers.

Not only through the reputation and important value instilled in the GITS company, but the performance of the company itself is also very important in building long and short term relationships. Corporate Performance according to Mendra et al ,. (2012) states that the description of the achievement of the implementation of an activity or program or policy in realizing the goals, objectives, mission and vision of the organization. In starting a project, GITS has several stages that must be mutually agreed upon by both parties and committed to achieving goals. This is done so that the running project will be on time and in accordance with the wishes of the customer. These stages are like the Business Requirement Study (BRM), Training, and finally the Go Live system simultaneously.

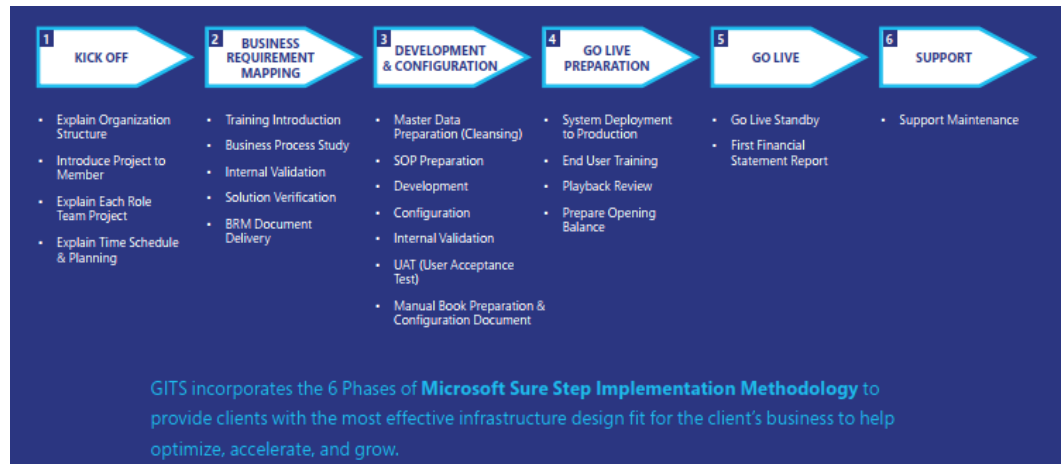

Figure 1.4 Stages - Stages of GITS Implementation

Source: Company Profile GITS 2020

There is a research gap in this study, namely the relationship between salesperson variables and relationship of quality. Based on the results of previous research conducted by Macintosh \& Lockshin (1997) 
which states that in a service company, a good relationship or a relationship can only be directly established between salespeople and their customers. In the sense that a salesperson of a service company dealing directly with customers will have a significant impact on customer commitment and customer loyalty. This contradicts the results of research conducted by Chen \& Mau (2009) which states that the relationship between salespeople and customers will always exist, but customers also create a person-to-store level relationship. With the intention of the relationship between the customer and the store or company, it will automatically establish itself as a result of the corporate reputation that the company itself brings.

Based on the explanation of the background of the problem that has been stated, this research takes the title "Analysis of Factors That Affect Customer Commitment and Customer Loyalty Customer Service ERP Systems PT. Global Industrial Technology Solutions (PT. GITS) In Surabaya”.

\section{Litterature Review}

\subsection{Theories and Hypotheses}

\subsubsection{Ethical Salesperson}

Ethical salesperson is a relevant competency related to the product, and is most often displayed in the form of information provided by salespeople (Crosby et al., 1990). According to Laith et al., (2012) ethical salesperson behavior has a significant impact on customer relationships and commitment through relationship quality of salespeople.

\section{H1: Ethical Salesperson has a significant effect on the Relationship Quality of Salesperson}

\subsubsection{Sales Expertise}

Sales expertise is defined as knowledge, experience, or skills that are relevant to certain topics that individuals in an organization or company have (Lagace et al., 1991). Bahm (1995) through his research proves that sales experts have a positive and significant effect on the relationship quality of salespeople, this is proven where sales who have in-depth knowledge of the products or services offered will have an impact on better relationships with customers compared to sales who do not have in-depth knowledge. regarding services / products.

\section{H2: Sales Expertise has a significant effect on the Relationship Quality of Salesperson}

\subsubsection{Service Performance}

According to Kasmir (2003), service performance in general is any activity that is intended or aimed at creating and establishing quality relationships of salespeople, through services that can meet customer wants and needs. This is supported by research conducted by Sanistasya (2015), which states that service performance has a significant effect on relationship quality of salespeople.

\section{H3: Service Performance has a significant effect on the Relationship Quality of Salesperson}

\subsubsection{Corporate Reputation}

Corporate reputation is the perception of customers and confidence in the organization as a result of past interactions of the organization both short and long term, which includes product impressions, anticipation of consistency in product and service quality, with no negative perspective (Caruana, 1997). According to Dick et al. (1990) The company's reputation will directly form a strong bond between customers and the company concerned so that it will influence customers in making choices.

H4: Corporate Reputation has a significant effect on the Relationship Quality of Institution 


\subsubsection{Corporate Performance}

According to Mendra and Widanaputra, (2012) corporate performance is a description of the achievement of the implementation of an activity or program or policy in realizing the goals, objectives, mission and vision of the organization. According to Ichniowski's (2011) research, there is a positive influence between the relationship quality of institutions on company performance because the good relationships that exist between clients and employees can improve company performance.

\section{H5: Corporate Performance has a significant effect on the Relationship Quality of Institution}

\subsubsection{Relationship Quality of Selesperson}

According to Lupiyodi (2012), relationship quality of salesperson is an activity or activity carried out by a company in order to increase the usefulness of a product or service offered by a company in order to create customer satisfaction and create a harmonious relationship between the two. Desi (2015) who argues that salesperson has an important role in the relationship quality of institutions where human resources are needed to determine the success of an institution. Employees or salespeople are very important because they can generate additional value for the company. Cronin \& Taylor (1992) stated that good quality in the relationship quality of salesperson provides a positive relationship in customer commitment.

H6: Relationship Quality of Salesperson has a significant effect on Relationship Quality of Institution

H7: Relationship Quality of Salesperson has a significant effect on Customer Commitment

\subsubsection{Relationship Quality of Institution}

According to Angelova (2011) relationship quality of institution is defined as a measure of whether an organization has the ability to not only meet customer needs but also exceed customer expectations through products or services. The quality of a company's relationship where customer satisfaction and trust can be seen as antecedents of commitment (Anderson \& Srinivasan, 2003).

H8: Relationship Quality of Institution has a significant effect on Customer Commitment

\subsubsection{Customer Commitment}

According to Thaicon et al. (2016) customer commitment is defined as customer belief and a lasting desire to maintain a relationship that can produce functional and emotional benefits. Customers who are classified as loyal tend to have high recommendation intentions, it can be said that loyal customers are customers who have committed to higher repurchases in the future and who are reluctant to move (Kim et al., 2007).

H9: Customer Commitment has a significant effect on Customer Loyalty

\subsubsection{Customer Loyalty}

According to Siagian and Cahyono (2014), customer loyalty is a firmly held commitment to consistently repurchasing selected products or services in the future, causing repeated purchases of products or services with the same brand, even though there are situational influences and potential marketing efforts. to cause the behavior to switch to a different brand of products or services. Sangadji and Shopiah (2013) define customer loyalty in the context of service marketing as a response that is closely related to pledges or promises by upholding the commitment that underlies the continuity of relationships, and is usually reflected in continuous purchases from the same service provider based on dedication and pragmatic constraints. 


\subsection{Research Model}

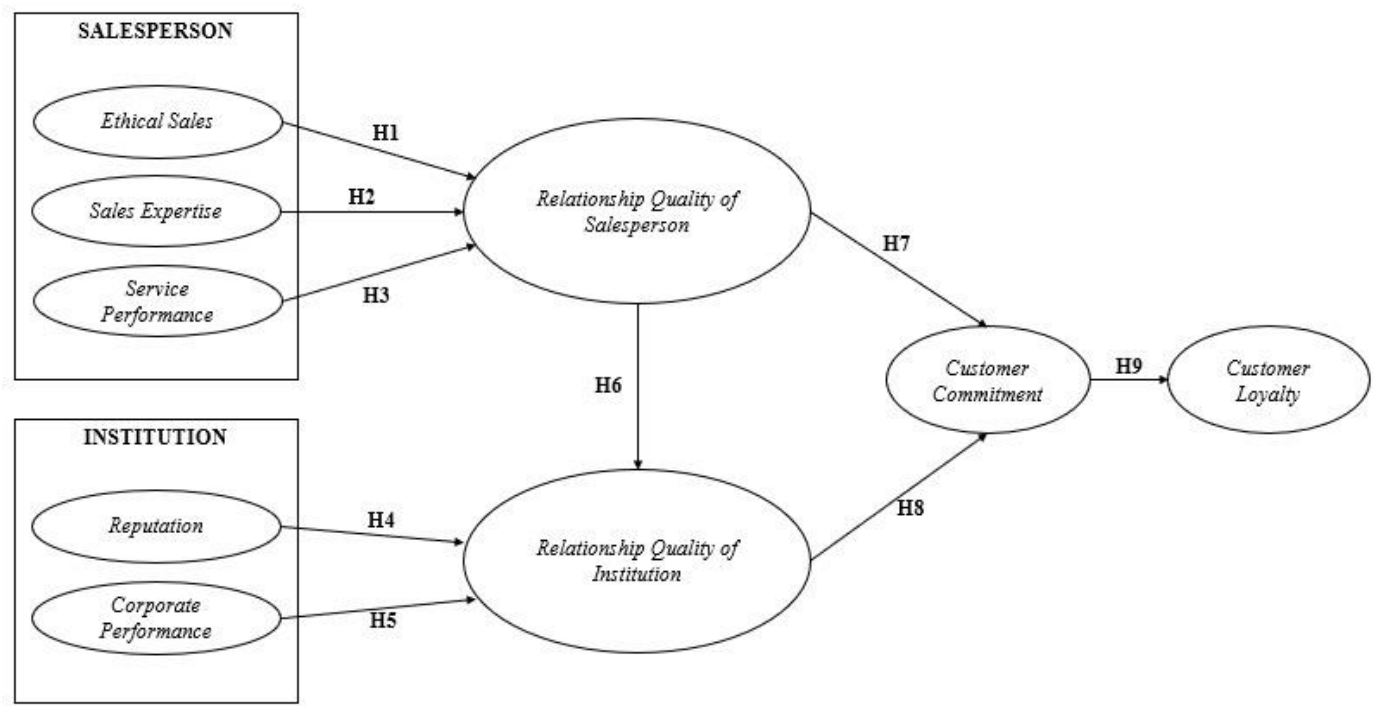

Figure 2.1: The Framework of Research Model

\section{Research Methods}

The research method used in this research is quantitative method, in which this method is a scientific approach to managerial and economic decision making. The population in this study were all customers / clients of PT. Global Industrial Technology Solutions. In this study, the sampling technique used was Probability Sampling with the full sampling method. Probability sampling according to Sugiyono (2017: 82) states that the sampling technique provides equal opportunities or opportunities for each element or member of the population to be selected as samples, this is because the number of customers / clients of PT. Global Industry Technology Solutions that can be identified with certainty and have the same opportunity to be sampled. Meanwhile, purposive sampling is a sampling technique by determining certain criteria (Sugiyono, 2008). In detail, the characteristics of the respondents can be described as follows: (1) Have been a GITS customer for about 1 year; (2) Residing in East Java or Jakarta; (3) Customers from medium to large companies; (4) Customers who have or have never used ERP services before. Based on data from PT. GITS Consulting, the number of customers who meet the specified criteria is 30 companies. based on this, this study uses a sample of 30 companies. 


\section{Results and Discussion}

\subsection{Assessment of Measurement Model}

Table 4.1: Simple Regression Ethical Salesperson (ES), Sales Expertise (SE), and Service Performance (SP) on Relationship Quality of Salesperson (RWS)

\begin{tabular}{|l|l|l|l|l|l|l|}
\hline Model / Variabel & $\mathrm{R}$ & $\mathrm{Adj} \mathrm{R}^{2}$ & $\mathrm{~F}_{\text {sig }}$ & Standardized Coefficients Beta & $\mathrm{t}_{\text {sig }}$ & Hypothesis \\
\hline ES, SE, SP *RWS & 0,978 & 0,953 & 0,000 & & & \\
\hline ES & & & & 0,283 & 0,020 & Accepted \\
\hline SE & & & & 0,320 & 0,001 & Accepted \\
\hline SP & & & & 0,411 & 0,001 & Accepted \\
\hline
\end{tabular}

Table 4.2: Multiple Regression Relationship Quality of Salesperson (RWS), Reputation (RE), and Corporate Performance (CP) on Relationship Quality of Institution (RWI)

\begin{tabular}{|l|l|l|l|l|l|l|}
\hline Model / Variabel & $\mathrm{R}$ & Adj R $^{2}$ & $\mathrm{~F}_{\text {sig }}$ & Standardized Coefficients Beta & $\mathrm{t}_{\text {sig }}$ & Hypothesis \\
\hline RWS,RE,CP *RWI & 0,977 & 0,950 & 0,000 & & & \\
\hline RWS & & & & 0,257 & 0,027 & Accepted \\
\hline RE & & & & 0,542 & 0,000 & Accepted \\
\hline CP & & & & 0,211 & 0,027 & Accepted \\
\hline
\end{tabular}

Table 4.3: Multiple Regression Relationship Quality Of Salesperson, Relationship Quality Of Institution to Customer Commitment

\begin{tabular}{|l|l|l|l|l|l|l|}
\hline Model / Variabel & $\mathrm{R}$ & Adj R $^{2}$ & $\mathrm{~F}_{\text {sig }}$ & Standardized Coefficients Beta & $\mathrm{t}_{\text {sig }}$ & Hypothesis \\
\hline RWS,RWI *CC & 0,969 & 0,935 & 0,000 & & & \\
\hline RWS & & & & 0,656 & 0,000 & Accepted \\
\hline RWI & & & & 0,327 & 0,022 & Accepted \\
\hline
\end{tabular}

Table 4.4: Simple Regression of Customer Commitment to Customer Loyalty

\begin{tabular}{|l|l|l|l|l|l|l|}
\hline Model / Variabel & $\mathrm{R}$ & $\mathrm{Adj}^{2}$ & $\mathrm{~F}_{\text {sig }}$ & Standardized Coefficients Beta & $\mathrm{t}_{\text {sig }}$ & Hypothesis \\
\hline $\mathrm{CC} * \mathrm{CL}$ & 0,680 & 0,444 & 0,000 & & & \\
\hline $\mathrm{CC}$ & & & & 0,680 & 0,000 & Accepted \\
\hline
\end{tabular}

Multiple regression test shows the influence of an independent variable on the dependent variable. The condition for a hypothesis is considered significant when the significance level is less than $0.05(\alpha=$ $5 \%)$. So that the results in this study are explained as follows:

\subsection{Hypotheses Testing}

Table 4.5: Summary of Testing Results.

\begin{tabular}{|l|l|}
\hline Hypotheses & Analysis \\
\hline H1: Ethical Sales has a significant effect on the Relationship Quality of Salesperson & Accepted \\
\hline H2: Sales Expertise has a significant effect on the Relationship Quality of Salesperson & Accepted \\
\hline $\begin{array}{l}\text { H3: Service Performance has a significant effect on the Relationship Quality of } \\
\text { Salesperson }\end{array}$ & Accepted \\
\hline H4: Reputation has a significant effect on the Relationship Quality of Institution & Accepted \\
\hline $\begin{array}{l}\text { H5: Corporate Performance has a significant effect on the Relationship Quality of } \\
\text { Institution }\end{array}$ & Accepted \\
\hline
\end{tabular}




\begin{tabular}{|l|l|}
\hline $\begin{array}{l}\text { H6: Relationship Quality of Salesperson has a significant effect on Relationship Quality of } \\
\text { Institution }\end{array}$ & Accepted \\
\hline H7: Relationship Quality of Salesperson has a significant effect on Customer Commitment & Accepted \\
\hline H8: Relationship Quality of Institution has a significant effect on Customer Commitment & Accepted \\
\hline H9: Customer Commitment has a significant effect on Customer Loyalty & Accepted \\
\hline
\end{tabular}

\subsection{Discussion}

\subsubsection{The effect of Ethical Salesperson on Relationship Quality of Salesperson}

The $t$ test results show a significance value below 0.05 for the first hypothesis which says Ethical Salesperson (ES) has a significant effect on the Relationship Quality of Salesperson (RWS) accepted at the sig level. $0.020<\mathrm{t}$ sig. 0.05 with a regression coefficient of 0.283 . The results of this study support the research conducted by Cronin \& Taylor, (1992) which shows that ethical salesperson's behavior is an important aspect in terms of increasing the relationship quality of salesperson because salesperson is a representative of the company's organizational image in their behavior and interactions with their customers. Research conducted by Laith et al., (2012) also states that ethical salesperson behavior has a significant impact on customer relationships and commitment through relationship quality of salesperson.

The results of this study indicate that the hypothesis is accepted. In that sense, the ethical salesperson at PT. Global Industri Teknologi Solusi will determine relationship quality of salesperson. The better the sales force of PT. Global Industry Technology Ethical solutions, so the quality of the relationship between sales and customers will be well established. The quality of the relationship between sales and customers is caused by sales communication capabilities, communication without pressure and having an attitude of listening to customers. So that this activity can create retail expectations for a long-term relationship.

\subsubsection{The effect of Sales Expertise on Relationship Quality of Salesperson}

The $t$ test results show a significance value below 0.05 for the second hypothesis which says Sales Expertise (SE) has a significant effect on the Relationship Quality of Salesperson (RWS) accepted at the sig level. $0.001<\mathrm{t}$ sig. 0.05 with a regression coefficient of 0.320 . The results of this study support the research conducted by Bahm, (1995) which shows that sales expertise has a positive and significant effect on relationship quality of salespeople. This means that salespeople who have in-depth knowledge of the products or services offered will have an impact on better relationships with customers compared to sales who do not have in-depth knowledge of the services / products. Research conducted by Kotler, (2002) states that sales expertise is a guidance on the management of intangible assets which are the pillars of relationship quality of salespeople in their relationship to create value (from products / services / solutions) that the company offers to its customers.

The results of this study indicate that the hypothesis is accepted. In a sense, the sales expertise possessed by the sales team from PT. Global Industri Teknologi Solusi will determine relationship quality of salesperson. Sales expertise determines the sustainability of an effective sales activity. Knowledge and information controlled by sales is necessary to build quality relationships with customers. Sales ability is evident after successfully influencing customers, which will certainly increase sales performance.

\subsubsection{The effect of Service Performance on Relationship Quality of Salesperson}

The $t$ test results show a significance value below 0.05 for the second hypothesis which says Service Performance (SE) has a significant effect on the Relationship Quality of Salesperson (RWS) accepted at the sig level. $0.001<\mathrm{t}$ sig. 0.05 with a regression coefficient of 0.411 . The results of this study support the research conducted by Sanistasya, (2015) which shows that service performance has a significant effect on relationship quality of salespeople. Service performance as referred to by Sanistasya is a tangible or intangible 
value enhancement activity related to a product or service directly or indirectly to meet customer expectations and provide quality relationship of salesperson which will ultimately have a good impact on the company. In another sense, according to Kasmir, (2003) service performance is any activity that is intended or aimed at creating and establishing quality relationships of salespeople, through services that can meet customer wants and needs.

The results of this study indicate that the hypothesis is accepted. In that sense, the service performance carried out by PT. Global Industri Teknologi Solusi will determine relationship quality of salesperson. Service quality of PT. Global Technology Industry makes openness for customers. In the end, consumers automatically evaluate the services they receive, in contrast to more objective goods because they exist. The personality of the service provided to the customer is more abstract, resulting in customer reactions in an effort to evaluate the service through what he receives and feels.

\subsubsection{The effect of Reputation on Relationship Quality of Institution}

The $t$ test results show a significance value below 0.05 for the second hypothesis that says reputation (RE) has a significant effect on the accepted relationship quality of salesperson (RWI) at the sig level. 0.027 $<\mathrm{t}$ sig. 0.05 with a regression coefficient of 0.257 . The results of this study support the research conducted by Herbig et al. (1994) who show that the reputation of a company is an award earned by a company because of the advantages that exist in the company. From the advantages that exist in the company, there is a good relationship with its customers.

The results of this study indicate that the hypothesis is accepted. In that sense, reputation made by PT. The Global Solution Technology Industry will determine the relationship quality of the institutions. Reputation of PT. Global Industrial Technology Solutions have a great influence on product purchases. Companies form a fundamental trademark rather than a product. Therefore, the company's reputation has a consequential effect on the purchasing process that is different from the impact of the brand image on existing products.

\subsubsection{The effect of Corporate Performance on Relationship Quality of Institution}

The $\mathrm{t}$ test results show a significance value below 0.05 for the second hypothesis which reads Corporate Performance (CP) has a significant effect on the relationship quality of salesperson (RWI) accepted at the sig level. $0.027<\mathrm{t}$ sig. 0.05 with a regression coefficient of 0.211 . The results of this study support the research conducted by Chen (2015) that company performance refers to environmental performance, social performance, economic performance, operational performance, and innovation performance. Relationship quality of salesperson of PT. Global Industry Technology Solutions are well formed which is an indicator of success between collaborative environmental, social and operational performance.

\subsubsection{The effect of Relationship Quality of Salesperson on Relationship Quality of Institution}

The t test results show a significance value below 0.05 for the second hypothesis which reads that the Relationship Quality of Salesperson (RWS) has a significant effect on the Relationship Quality of Institution (RWI) accepted at the sig level. $0.027<\mathrm{t}$ sig. 0.05 with a regression coefficient of 0.257 . These results indicate the existence of consumer confidence in using the company's services / products. Singh \& Sirdeshmukh (2000) emphasized that trust is an important mediating factor between customer behavior before and after buying a service / product. This can lead to long-term loyalty and strengthen relations between the two parties.

The results of this study indicate that the hypothesis is accepted. It means, relationship quality of salesperson of PT. The Global Solution Technology Industry will determine the relationship quality of the institutions. The quality of communication between the salesperson of PT. Global Industrial Technology 
Solutions have a great influence on the relationship between companies. The company has succeeded in creating a form of cooperation that is futuristic and of course mutually beneficial. Panda (2014) asserts that relationship marketing exists as an alternative to building and maintaining customer loyalty.

\subsubsection{The effect of Relationship Quality of Salesperson on Customer Commitment}

The $\mathrm{t}$ test results show a significance value below 0.05 for the second hypothesis which reads Relationship Quality of Salesperson (RWS) has a significant effect on Customer Commitment (CC) accepted at the sig level. $0,000<\mathrm{t}$ sig. 0.05 with a regression coefficient of 0.969 . The results of this study support research conducted by Susanta et al (2013) that it is cheaper to retain satisfied customers than to attract new ones, marketers focus on attracting and retaining profitable customers, by building long-term relationships for the common good. This means that customers will continue to maintain commitments in line with the behavior given by the company's salesperson. Salesperson is able to strengthen already strong relationships and to convert indifferent customers into loyal customers.

The results of this study indicate that the hypothesis is accepted. It means, relationship quality of salesperson of PT. Global Industry Technology Solutions has a significant effect on customer commitment. PT. Global Industrial Technology Solutions is able to build consumer loyalty through quality salesperson work. Salesperson is able to build good quality relationships between customers with one another. In the end, consumer trust in the company is created. Present trust is influenced by consumers' trust in quality and service that is consistent, honest, responsible, and humble.

\subsubsection{The effect of Relationship Quality of Institution on Customer Commitment}

The $\mathrm{t}$ test results show a significance value below 0.05 for the second hypothesis which reads Relationship Quality of Institution (RWI) has a significant effect on Customer Commitment (CC) accepted at the sig level. $0.022<\mathrm{t}$ sig. 0.05 with a regression coefficient of 0.969 . The results of this study support the research conducted by Hennig-Thurau (2000) that the initial theory underlying the current study is the quality of relationship quality, an important relationship for the marketing phenomenon which refers to the closeness or strength of relationships that tends to increase customer loyalty. Hajli (2014) and Sheikh et al (2019) further explained that the quality of the relationship generates support for colleagues and companies in expanding the network.

The results of this study indicate that the hypothesis is accepted. This means that the relationship quality of the institution of PT. Global Industry Technology Solutions has a significant effect on customer commitment. PT. Global Industrial Technology Solutions is here to create the greatest opportunities possible in establishing cooperative relationships and supporting each other in marketing. This is based on the quality of the relationship that occurs, measured by how much trust, satisfaction and customer commitment.

\subsubsection{The effect of Customer Commitment on Relationship Quality of Salesperson}

The $\mathrm{t}$ test results show a significance value below 0.05 for the second hypothesis which says that customer commitment has a significant effect on customer loyalty received at the sig level. $0,000<\mathrm{t}$ sig. 0.05 with a regression coefficient of 0.680 . The results of this study support previous research conducted by Sondoh et al (2007) that customer loyalty is the result of the hard work of the company team that makes customers commit through meeting customer needs. This means that customer satisfaction is a priority to meet the needs, wants, and expectations of customers for products / services or services that have been fulfilled or even exceeded, resulting in repeated purchases. Customer satisfaction has several benefits, in addition to increasing customer loyalty it also increases reputation and increases employee competence.

The results of this study indicate that the hypothesis is accepted. This means that customer commitment has a significant effect on customer loyalty at PT. Global Industrial Technology Solutions. This incident 
shows that PT. Global Industri Teknologi Solusi maintains stability of customer satisfaction by fulfilling product / service needs. Touzani \& Temessek (2009) further explains the most important part is that customer loyalty is a partnership that is committed and full of influence between consumers and brands.

\section{Conclusion}

Based on the data processing that has been done, the results obtained are eight hypotheses accepted and three hypotheses rejected. There is a significant relationship between functions on customer satisfaction, usability with customer satisfaction, applications for customer satisfaction, customer support for customer satisfaction, unit features on customer satisfaction, corporate factors on customer satisfaction, customer satisfaction with customer loyalty, and switching costs for customer loyalty. Meanwhile, an insignificant relationship was found between design on customer satisfaction, price on customer satisfaction, and corporate image on customer satisfaction.

\subsection{Managerial Implications}

Table 5.1: Managerial Implications

\begin{tabular}{|c|c|}
\hline Current Research & Managerial Implications \\
\hline $\begin{array}{l}\text { Ethical Salesperson is one } \\
\text { element that is the focus in } \\
\text { the process to improve the } \\
\text { Relationship Quality of } \\
\text { Salesperson. }\end{array}$ & $\begin{array}{l}\text { - Providing good and unique product sales information, by providing } \\
\text { detailed information about product descriptions through short videos that } \\
\text { are shown to clients while selling products. } \\
\text { - Conduct research or collect any information that the customer needs } \\
\text { from a meeting between PT. GITS with customers. The information } \\
\text { obtained can also be in the form of a questionnaire that has been filled in } \\
\text { by the customer. The sales team can also provide ERP implementation } \\
\text { best practices for things that are standard / commonly applied in several } \\
\text { types of companies (factories, etc.). } \\
\text { - Learn first the type of company from its customers, whether this } \\
\text { customer is a service company or manufacturing company or even a } \\
\text { retail company. Because from there the sales team can provide solutions } \\
\text { and products in accordance with the company's customers. }\end{array}$ \\
\hline $\begin{array}{l}\text { Sales Expertise is one } \\
\text { element that is the focus in } \\
\text { the process of improving the } \\
\text { Relationship Quality of } \\
\text { Salesperson. }\end{array}$ & $\begin{array}{l}\text { - Provide regular training to all employees, both new employees and those } \\
\text { who have been at PT. GITS, so that each employee has knowledge about } \\
\text { the ERP systems that are sold by the company itself. Not only general } \\
\text { knowledge about technology currently being used in the world is also the } \\
\text { most important thing so that the sales team and other employees always } \\
\text { follow the technological trends of the times. PT. Global Industri } \\
\text { Teknologi Solusi can also recruit employees who have good IT basics so } \\
\text { that they also have the basics of the products sold by the company. } \\
\text { - Provide clear information on the flow of complaints or technical requests } \\
\text { to customers at the time of the agreement. This also makes PT. Global } \\
\text { Industrial Technology Solutions can quickly solve and prioritize } \\
\text { technical problems desired by customers. PT. Global Industri Teknologi } \\
\text { Solusi also makes web-based customer complaint systems. } \\
\text { - Utilizing various kinds of social media such as Facebook, Instagram, } \\
\text { company websites to share various information on the products they sell } \\
\text { to potential buyers and those who are already customers. }\end{array}$ \\
\hline
\end{tabular}


Service Performance is one element that is the focus in the process to improve the Relationship Quality of Salesperson.
- After each customer / client who has entered the Go Live Implementation stage, the 101 sales team should provide them with an evaluation form so that their service performance can grow from year to year.

- Organizing employee self-development programs, especially the sales team, so that each employee can understand their potential. Providing good facilities whether it's facilities in the office or tools that are used daily for work such as laptops, etc. Things like this also provide a sense of comfort at work and give employees a sense of belonging to the company as their second home. Because a happy heart while working will increase the productivity of its employees.

Reputation is one of the elements that is the focus in the process of improving the Relationship Quality of Institution.

- Create a membership loyalty program. This program can provide various attractive offers for loyal customers of PT. GITS whether it has been 1 year or more. The offer can be in the form of free maintenance service, free custom modules for the ERP systems they already use, and even free events for customers who join this program.
- Provides a website that can be seen when prospective customers search for PT. GITS Consulting via search engine (google). From the website, prospective customers can find the history, vision, facilities of PT. GITS, customer messages that have been successfully implemented, to complete success stories from GITS customers.

- Opening new branches in potential big cities in Indonesia, for example in Bekasi City, which is an industrial area. That way PT. Global Industrial Technology Solutions have even greater opportunities to get projects from various types of companies.

Corporate Performance is one of the elements that is the focus in the process of improving Relationship Quality Of Institution.

- Create a friendly corporate environment for all customers. Customers are given the right to transfer information, meaning that when customers brainstorm, company employees will provide persuasive directions according to company regulations.

- Offers a 24 hour service where employees are also committed to being ready to provide customer service via phone / chat. But companies also have to provide useful training to build and create employees who love their jobs. All of that in order to implement a 24-hour service commitment to employees who are able and ready to serve customers anytime and anywhere, especially if there is an urgent situation for the customer / client.

- Revitalizing facilities according to the needs and capabilities of the company in providing facilities. Facilities are of good quality, that is, they can be used for a relatively long period of time. Good facilities are an important indicator for company employees to carry out their duties and responsibilities.

Relationship Quality Of Salesperson is one element that is the focus in the process of improving the Relationship Quality Of
- Make small changes to the conversation pattern in order to make the customer feel comfortable and happy to hear the conversation the sales team is having. Given that PT. GITS Consulting is a service company, so details like this must be paid attention to. Another thing the sales team can provide examples of real cases that can be resolved during 


\begin{tabular}{|c|c|}
\hline $\begin{array}{l}\text { Institution and Customer } \\
\text { Commitment. }\end{array}$ & $\begin{array}{l}\text { explaining or during presentation in front of customers. Especially when } \\
\text { providing solutions to the constraints the customers have. } \\
\text { - Carry out progress transparency or the latest updates regarding the } \\
\text { progress of each ongoing project, by providing general information on } \\
\text { the PT. GITS where customers who have already dealt can monitor their } \\
\text { respective projects. This is done in order to avoid miscommunication } \\
\text { between the two parties and to build trust in customers. } \\
\text { - Give appreciation or awards in the form of employee of the month to } \\
\text { employees. This award aims to encourage employees to always produce } \\
\text { the best performance performance so that service to clients is expected to } \\
\text { produce professional service so that clients are satisfied when consulting } \\
\text { with PT. GITS Consulting. } \\
\text { Offers a variety of payment facilities to its customers. Such as offering } \\
\text { various price packages, and customers who have contracted with a large } \\
\text { nominal value can be offered gradual payments so that customers } \\
\text { experience the variety of transactions offered. }\end{array}$ \\
\hline $\begin{array}{l}\text { Relationship Quality Of } \\
\text { Institution is one of the } \\
\text { elements that is the focus in } \\
\text { the process of increasing } \\
\text { Customer Commitment. }\end{array}$ & $\begin{array}{l}\text { - Give more attention to customers. The ability to really listen to } \\
\text { customers is quite important. } \\
\text { - Provide VIP facilities to clients who use PT. GITS Consulting for more } \\
\text { than } 3 \text { years. The facilities can be in the form of discounted prices, free } \\
\text { maintenance service, or even free entrance events held by PT. GITS. } \\
\text { That way the customer company will feel appreciated for their loyalty in } \\
\text { using the services of PT. GITS Consulting is noticed. } \\
\text { - Creating a good customer perception of PT. GITS Consulting. } \\
\text { Perceptions are formed after the customer has had an impressive } \\
\text { experience with previous services. The company will make every effort } \\
\text { to build high satisfaction through meeting and adequate customer needs. } \\
\text { - Maintaining the current method, namely PT. GITS always provides } \\
\text { direction or some input on the constraints that exist in each phase of } \\
\text { implementation. }\end{array}$ \\
\hline $\begin{array}{l}\text { Customer Commitment is } \\
\text { one element that is the focus } \\
\text { in the process of increasing } \\
\text { Customer Loyalty. }\end{array}$ & $\begin{array}{l}\text { - Understand customer wants from the customer's point of view the first } \\
\text { time you consult. From the seller's point of view, the goal is to persuade } \\
\text { the customer to commit or return after completing the transaction the } \\
\text { first time. The solution is in three main things, namely providing the best } \\
\text { product quality, adjusting it to the wishes and needs of customers so that } \\
\text { customers get value / value that exceeds expectations which make clients } \\
\text { committed to PT. GITS Consulting. } \\
\text { - Providing an online platform as a new consulting experience for PT. } \\
\text { GITS Consulting remembers that during this pandemic, customers are } \\
\text { reluctant to go to GITS offices or vice versa } \\
\text { - Hold events or seminars for its customers regarding the introduction of } \\
\text { the latest products that have the potential to be applied / implemented in } \\
\text { the customer's company. }\end{array}$ \\
\hline
\end{tabular}




\subsection{Recommendation}

Looking at the results of existing research where there are still many limitations to the research conducted by the author, the recommendations that can be submitted by the author are as follows:

- Seeing the limitations regarding the object of research that only takes respondents, namely customers of PT. Global Solution Technology Industry in Surabaya, it is hoped that the next research using the same or modified model can be applied to different objects to get more general results on the factors that affect Customer Loyalty.

- Further research is expected to complement the existing variables in this study so that it can further enhance the understanding of the factors that affect customer loyalty, for example, such as the addition of other variables such as Technical Expertise and Consultant Expertise.

- In addition, it is hoped that the AMOS 16.0 software can use the Structural Equational Model (SEM) in further research

\section{References}

Almajali, A. Y., Alamro, S. A., \& Al-Soub, Y. Z. (2012). Factors affecting the financial performance of Jordanian insurance companies listed at Amman Stock Exchange. Journal of Management research, 4(2), 266.

Anderson, E., \& Weitz, B. (1992). The use of pledges to build and sustain commitment in distribution channels. Journal of marketing research, 29(1), 18-34.

Angelova, B., \& Zekiri, J. (2011). Measuring customer satisfaction with service quality using American Customer Satisfaction Model (ACSI Model). International journal of academic research in business and social sciences, 1(3), 232.

Ardianto dan Soemirat. 2004. Dasar-Dasar Public Relations;. Bandung. PT Remaja Rosdakarya

Barnes, W. L., Dereux, A., \& Ebbesen, T. W. (2003). Surface plasmon subwavelength optics. nature, 424(6950), 824-830.

Ben-Hur, A., \& Weston, J. (2010). A user's guide to support vector machines. In Data mining techniques for the life sciences (pp. 223-239). Humana Press.

Bhatia, V., Flowerdew, J., \& Jones, R. H. (Eds.). (2008). Advances in discourse studies. Routledge.

Caruana, A. (1997). Corporate reputation: concept and measurement. Journal of product \& brand management.

Chusniyah, T., \& Pitaloka, A. (2012). Analisis Wacana pada Media Internet terhadap Optimisme dan Harapan tentang Masa Depan Indonesia. Jurnal Sains Psikologi, 2(2), 67-81.

Cronin Jr, J. J., \& Taylor, S. A. (1992). Measuring service quality: a reexamination and extension. Journal of marketing, 56(3), 55-68.

DA, C., SF, L., \& MG, L. (1990). Long term effects of withholding phosphate application on North Island hill country: Economics. In Proceedings of the New Zealand Grassland Association (Vol. 51, pp. 29-34).

Demirgüneş, K. (2015). Determinants of target dividend payout ratio: A panel autoregressive distributed lag analysis. International Journal of Economics and Financial Issues, 5(2), 418-426. 
Fombrun, C. J., \& van Riel, C. B. (2003). Reputation und Unternehmensergebnis_zentrale Resultate einer empirischen Studie. In Ganzheitliches Corporate Finance Management (pp. 291-298). Gabler Verlag.

Gilovich, T., Griffin, D., \& Kahneman, D. (Eds.). (2002). Heuristics and biases: The psychology of intuitive judgment. Cambridge university press.

Goffeau, A., Barrell, B. G., Bussey, H., Davis, R. W., Dujon, B., Feldmann, H., ... \& Louis, E. J. (1996). Life with 6000 genes. Science, 274(5287), 546-567.

Hansen, C. M., \& Lasen, J. M. (2014). Basic Life Support Knowledge, self-reported skills and fears in Danish hight school students and effect of a single 45-min training session run by junior doctors; a prospective cohort study. Resuscitation and Emergency Medicine:22-24

Kandampully, J., Zhang, T. C., \& Jaakkola, E. (2018). Customer experience management in hospitality. International Journal of Contemporary Hospitality Management.

Keh, H. T., \& Xie, Y. (2009). Corporate reputation and customer behavioral intentions: The roles of trust, identification and commitment. Industrial marketing management, 38(7), 732-742.

Kotler, P., \& Lee, N. (2005). Best of breed: When it comes to gaining a market edge while supporting a social cause,"corporate social marketing" leads the pack. Social marketing quarterly, 11(3-4), 91-103.

Kotler, Philip and Kevin Lane Keller, (2016): Marketing Management, 15th Edition New Jersey: Pearson Pretice Hall, Inc. Kotler, Philip \& Gerry Armstrong, (2014): Principle

Kotler, Philip dan Keller, 2007, Manajemen Pemasaran, Jilid I, Edisi Kedua belas, PT. Indeks, Jakarta.

Lagace, R. R., Dahlstrom, R., \& Gassenheimer, J. B. (1991). The relevance of ethical salesperson behavior on relationship quality: the pharmaceutical industry. Journal of Personal Selling \& Sales Management, 11(4), 39-47.

Lewis, K. D., \& Booms, B. (1983). Berry et al. Shostack, G. y Upah, G (1987).“Emerging Perspectives on services marketing". American Marketing Association. Chicago.

Liss, M. A., Chang, A., Santos, R., Nakama-Peeples, A., Peterson, E. M., Osann, K., ... \& Dash, A. (2011). Prevalence and significance of fluoroquinolone resistant Escherichia coli in patients undergoing transrectal ultrasound guided prostate needle biopsy. The Journal of urology, 185(4), 1283-1288.

Lupiyoadi, Rambat. 2001. Manajemen Pemasaran Jasa, Teori dan Praktek. Edisi Pertama. Jakarta: Salemba Empat

Moeheriono. 2012. "Pengukuran Kinerja Berbasis Kompetensi”. Jakarta: Raja Grafindo Persada

Mol, H. G., Rooseboom, A., van Dam, R., Roding, M., Arondeus, K., \& Sunarto, S. (2007). Modification and re-validation of the ethyl acetate-based multi-residue method for pesticides in produce. Analytical and bioanalytical chemistry, 389(6), 1715-1754.

Moorman, C., Zaltman, G., \& Deshpande, R. (1992). Relationships between providers and users of market research: The dynamics of trust within and between organizations. Journal of marketing research, 29(3), 314-328.

Morgan, R. M., \& Hunt, S. D. (1994). The commitment-trust theory of relationship marketing. Journal of marketing, 58(3), 20-38.

Nugrahayu, E. R., dan Retnani, E. D. (2016). Penerapan Metode Balanced Scorecard Sebagai Tolak Ukur 
Pengukuran Kinerja Perusahaan. Jurnal Ilmu dan Riset Akuntansi, 4(10).

Palumbo, A., Chanan-Khan, A., Weisel, K., Nooka, A. K., Masszi, T., Beksac, M., ... \& Mark, T. M. (2016). Daratumumab, bortezomib, and dexamethasone for multiple myeloma. New England Journal of Medicine, 375(8), 754-766.

Priansa, D. J. (2017). Pengembangan Strategi Dan Model Pembelajaran: Inovatif, Kreatif, dan prestatif dalam memahami peserta didik.

Román, S., \& Ruiz, S. (2005). Relationship outcomes of perceived ethical sales behavior: the customer's perspective. Journal of Business Research, 58(4), 439-445.

Sangadji, E.M., dan Sopiah. 2013. Prilaku Konsumen: Pendekatan Praktis Disertai:Himpunan Jurnal Penelitian. Yogyakarta: Penerbit Andi.

Shenkar, O., \& Yuchtman-Yaar, E. (1997). Reputation, image, prestige, and goodwill: An interdisciplinary approach to organizational standing. Human Relations, 50(11), 1361-1381.

Siagian, H., \& Cahyono, E. (2014). Analisis website quality, trust dan loyalty pelanggan online shop. Jurnal Manajemen Pemasaran, 8(2), 55-61.

Songkhla, W. N. (2016). Conservation of mural paintings. SPAFA Digest (1980-1990), 1(1).

Tang, Y. L., Yin, H. L., Chen, S. J., Liu, Y., Zhang, W. J., Jiang, X., ... \& Yang, D. X. (2014). Measurementdevice-independent quantum key distribution over $200 \mathrm{~km}$. Physical review letters, 113(19), 190501.

Tran, M. A., Nguyen, B., Melewar, T. C., \& Bodoh, J. (2015). Exploring the corporate image formation process. Qualitative Market Research: An International Journal.

Utami, C. W. (2010). Manajemen Ritel_Strategi dan Implementasi Operasional Bisnis Ritel Modern Di Indonesia.

Van Riel, C., \& Fombrun, C. (1996). Essentials of corporate communication: Implementing practices for effective reputation management.

Waluyo, P., \& Pamungkas, A. (2003). Analisis Perilaku Brand Switching Konsumen dalam Pembelian Produk Handphone di Semarang. Jurnal Bisnis dan Ekonomi.

Warm, J. S., Parasuraman, R., \& Matthews, G. (2008). Vigilance requires hard mental work and is stressful. Human factors, 50(3), 433-441.

Weiss, A. M., Lurie, N. H., \& MacInnis, D. J. (2008). Listening to strangers: whose responses are valuable, how valuable are they, and why?. Journal of marketing Research, 45(4), 425-436.

Widanaputra, A A GP. 2015. Pengaruh Good Corporate Governance dan Konservatisme Akuntansi Pada Manajemen Laba. E-Jurnal Akuntansi Universitas Udayana 10.3 (2015): 663-676. ISSN: 2302-8556

Yukl, G., Gordon, A., \& Taber, T. (2002). A hierarchical taxonomy of leadership behavior: Integrating a half century of behavior research. Journal of leadership \& organizational studies, 9(1), 15-32. 


\section{Appendix}

Table 6.1: The Items List Used in the study

Customer Loyalty
1. I am willing to recommend PT. GITS Consulting to my supervisor.
2. I am willing to recommend PT. GITS Consulting to other companies.
3. I always say positively about PT. GITS Consulting to others.

\section{Customer Commitment}

1. I am committed to having a long term relationship with PT. GITS Consulting.

2. I am committed to choosing PT. GITS Cosulting in developing company information systems.

3. I am committed to continuing to consult about the company's ERP system development with PT. GITS Consulting.

\section{Relationship With The Salesperson}

1. I am satisfied with the advice from the sales team from PT. GITS Consulting.

2. I feel satisfied when transacting with the sales team from PT. GITS Consulting.

3. I am satisfied with the performance of the sales team of PT. GITS Consulting.

4. I believe the suggestion of the Sales team of PT. GITS Consulting.

5. I believe in the transactions I made with the sales team from PT. GITS Consulting.

6. I believe in the performance of the sales team of PT. GITS Consulting.

\section{Relationship With The Institution}

1. I am satisfied with PT. GITS Consulting.

2. I feel satisfied with the way PT. GITS Consulting in handling the needs of our company.

3. I am satisfied with the decisions made by PT. GITS Consulting.

4. I believe in PT. GITS Consulting.

5. I believe in the way PT. GITS Consulting handles the needs of our company.

6. I believe in the decisions of PT. GITS Consulting.

\section{Ethical Salesperson Behavior}

1. In my opinion, the sales team from PT. GITS Consulting sells their product with a clear statement / explanation to me.

2. In my opinion, the sales team from PT. GITS Consulting will only sell products that are suitable for my company.

3. In my opinion, the sales team of PT. GITS Consulting always prioritizes the needs of its customers first

Sales Expertise

1. In my opinion, the sales team from PT. GITS Consulting has extensive knowledge in the field of information technology.

2. In my opinion, the sales team from PT. GITS Consulting provides a lot of useful information for the development of my company business.

3. In my opinion, the sales team of PT. GITS Consulting is always able to provide maximum service for technical requests

\section{Service Performance}

1. In my opinion, the sales team from PT. GITS Consulting shows the quantity of performance according to the needs of our company.

2. In my opinion, the sales team from PT. GITS Consulting shows the quality of work in accordance with the demands of our company.

3. In my opinion, the sales team from PT. GITS Consulting shows performance improvement according to the suggestions given by our company. 
Corporate Reputation

1. In my opinion, PT. GITS Consulting has a reputation as an honest (open) company.

2. In my opinion, PT. GITS Consulting has a reputation as the best project partner.

3. In my opinion, PT. GITS Consulting has a reputation as a company that always provides the best service.

Corporate Performance

1. In my opinion, PT. GITS Consulting always provides the quantity of facilities according to its promise.

2. In my opinion, PT. GITS Consulting shows the best quality of service

3. In my opinion, PT. GITS Consulting shows its performance as a professional company. 